\title{
Pistachio Rootstocks Influence Scion Growth and Ion Relations under Salinity and Boron Stress
}

\author{
L. Ferguson ${ }^{1}$ \\ Kearney Agricultural Center, University of California. 9240 South Riverbend, Parlier, CA 93648
}

\author{
J.A. Poss \\ U.S.Department of Agriculture, AgriculturalResearch Service, George E.Brown,Jr., SalinityLaboratory, \\ 450 W. Big Springs Road, Riverside, CA 92507
}

S.R. Grattan

Department of Land, Air and Water Resources, University of California, Davis, CA 95616

C.M. Grieve, D. Wang, C. Wilson, and T.J. Donovan

U.S.Department of Agriculture, AgriculturalResearch Service, George E.Brown, Jr., SalinityLaboratory, 450 W. Big Springs Road, Riverside, CA 92507

C.-T. Chao
Department of Botany and Plant Sciences, University of California, Riverside, CA 92521

\begin{abstract}
AdDitional INDEX wORDs. biomass production, chlorophyll, foliar injury, ion relations, Pistacia vera, salt tolerance, trunk diameter

Abstract. Performance of 'Kerman' pistachio (Pistacia vera $L$.) trees on three rootstocks (P.atlantica Desf., P.integerrima Stewart and 'UCB-1', a $P$. atlantica $X$ P. integerrima hybrid) was evaluated with 2 -year-old trees grown in sand-tank lysimeters under combined $\mathrm{SO}_{4}{ }^{2-}$ and $\mathrm{Cl}^{-}$salinity and boron (B) stress for 6 months. Four salinity treatments were imposed by irrigating the plants with water at electrical conductivity $\left(\mathrm{EC}_{\mathrm{iw}}\right)$ of 3.5, 8.7,12, or $16 \mathrm{dS} \cdot \mathrm{m}^{-1}$ each containing $B$ at $10 \mathrm{mg} \cdot \mathrm{L}^{-1}$. Growth of 'Kerman' was evaluated based on increase in total leaf area, increase in trunk diameter, and total above-ground biomass production. All growth parameters decreased as salinity increased, but were not significant until $\mathrm{EC}_{\mathrm{iw}}$ exceeded $12 \mathrm{dS} \cdot \mathrm{m}^{-1}$. However, growth of 'Kerman' on $P$. atlantica and 'UCB-1' was considerably better than on $P$. integerrima at $16 \mathrm{dS} \cdot \mathrm{m}^{-1}$. The onset and severity of foliar injury differed among scions and treatments and was attributed primarily to $B$ toxicity, rather than the effects of salinity. Concentrations of $B$ in injured leaf tissue ranged from 1000 to $2500 \mathrm{mg} \cdot \mathrm{kg}^{-1}$. Leaf injury decreased with increasing salinity, although leaf $B$ was not significantly reduced suggesting an internal synergistic interaction between $B$ and other mineral nutrients. However for $P$. vera on $P$.

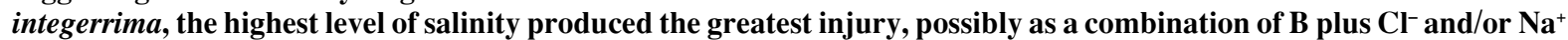
toxicity. Leaf transpiration, stomatal conductance, and chlorophyll concentration of $P$. vera, determined by steady-state porometry, were also reduced to a greater degree by combined salinity and $B$ when budded on $P$. integerrima than on the other two rootstocks.
\end{abstract}

Although pistachio (Pistacia vera) trees are classified as a moderately salt-sensitive crop (Maas and Grattan, 1999), they are better adapted to salinity than most other perennial fruit and nut crops (Walker et al., 1987). The ability to tolerate adverse water quality creates a niche for pistachio in areas where soils are saline or where saline or moderately saline water supplies are used for irrigation. Saline-sodic drainage waters in the San Joaquin Valley (SJV) of California are dominated by $\mathrm{SO}_{4}{ }^{2-}$ and often contain high concentrations of boron (B) in addition to increased salts. Little information, however, exists on the interaction of these two stresses, particularly in pistachio. Currently, the three major rootstocks of the California pistachio industry are $P$. atlantica, $P$. integerrima, and the $P$. atlantica $\times P$. integerrima hybrid, 'UCB1 ' (Brown et al., 1994). Information on differences in the overall performance (e.g., growth, injury, and ion relations) of commer-

Received for publication 14 Sept 2000. Accepted for publication 4 Dec. 2001. The authors thank Donald A. Layfield for ion analyses and Phyllis Nash for statistical analyses. Jenny Espiritu and Arnold Saladino provided technical assistance with leaf porometry, SPAD readings, and sample processing. Mention of a trademark, proprietary product, or vendor does not constitute a guarantee or warranty of the product by the U.S. Department of Agriculture or the University of California and does not imply its approval to the exclusion of other products or vendors that may also be suitable.

${ }^{1}$ Corresponding author: e-mail cgrieve@ussl.ars.usda.gov. cial pistachio grafted on different rootstocks when exposed to high salt and B stress will be of increasing importance if this crop continues to be developed commercially in the western SJV or in other areas of the world impacted by salinity or high B.

Salinity studies with pistachio, typically under greenhouse conditions, have evaluated primarily either seedling rootstocks or seedlings derived from bearing $P$. vera cultivars growing on their own roots. For example, pistachio salt tolerance has been examined in Iran with $P$. vera seedlings grown in small pots in a greenhouse. Sepaskhah and Maftoun (1988) found the average root-zone salinity $\left(\mathrm{EC}_{\mathrm{e}}\right)$ for a $50 \%$ reduction in shoot growth was between 7.9 and $10 \mathrm{dS} \cdot \mathrm{m}^{-1}$ depending on the seedling source. Shoot growth ceased when $\mathrm{EC}_{\mathrm{e}}$ reached 15.5 to $20.6 \mathrm{dS} \cdot \mathrm{m}^{-1}$. In an earlier greenhouse study, Sepaskhah et al. (1985) determined that the relative shoot biomass of $P$. vera 'Fandoghi' seedlings was reduced by $50 \%$ when the trees were subjected to an external solution $\mathrm{Cl}^{-}$concentration of $159 \mathrm{~mm}\left(\approx 16.3 \mathrm{dS} \cdot \mathrm{m}^{-1}\right)$ for $140 \mathrm{~d}$. From results of a greenhouse study, Walker et al. (1987) reported that $\mathrm{Cl}^{-}$concentrations of $150 \mathrm{mM}$ had no significant effect on dry matter production of the rootstocks $P$. atlantica and $P$.terebinthus provided the external medium was salinized gradually over a 3week period from an initial irrigation solution concentration of 30 $\mathrm{mm} \mathrm{Cl}{ }^{-}$. Although Walker et al. (1987) conceded that growth reductions will occur as treatment duration increases, they con- 
cluded there is no difference between $P$. atlantica and $P$. vera as a rootstock for salt tolerance. Consequently, from a salt tolerance standpoint, there is no advantage of the rootstocks over ownrooted $P$. vera in pistachio production. In an outdoor lysimeter study under semiarid conditions, Picchioni et al. (1990) measured an average $33 \%$ reduction in seedling stem elongation at soil solution salinities of $\approx 12.6 \mathrm{dS} \cdot \mathrm{m}^{-1}$ for a $P$. integerrima $\times P$. atlantica hybrid ('Gold II'), $P$. atlantica, and $P$. terebinthus seedlings.

Pistachio rootstocks can also be influenced adversely by B in the root zone. Dry weights (DWs) of $P$. vera seedlings from two cultivars grown in a greenhouse for 6 months in nonsaline clay soils amended with $\mathrm{B}$ at $100 \mu \mathrm{g} \cdot \mathrm{g}^{-1}$ soil were reduced by $\approx 20 \%$ to $67 \%$, depending on soil $\mathrm{N}$ concentrations and seedling source (Sepaskhah and Maftoun, 1994). The concentration threshold for $\mathrm{B}$ toxicity symptoms in pistachio leaves is reported to be $\approx 1000$ $\mathrm{mg} \cdot \mathrm{kg}^{-1} \mathrm{DW}$ and the injury is usually characterized by marginal necrosis on older leaves late in the season (Ashworth et al., 1985). Visible symptoms of $\mathrm{Cl}^{-}$toxicity are often quite similar to those of B (i.e., marginal necrosis and leaf scorch) and have been observed in pistachio at leaf $\mathrm{Cl}^{-}$concentrations of $\approx 2 \%$ (Ashworth. et al., 1985).

Few pistachio $\times$ salinity growth response studies have involved salts other than $\mathrm{NaCl}$. However, in California, as in many arid parts of the world, irrigation water supplies, particularly ground water sources, contain a mixture of $\mathrm{Na}^{+}, \mathrm{SO}_{4}{ }^{2-}, \mathrm{Cl}^{-}, \mathrm{Mg}^{2+}$, and $\mathrm{Ca}^{2+}$ salts in addition to high $\mathrm{B}$. A companion field study in the western SJV has been underway since 1994 where the performance of 'Kerman' pistachio on several popular rootstocks ('UCB-1', P . atlantica, 'Pioneer Gold I', and 'Pioneer Gold II') is being evaluated at five salinity $+\mathrm{B}$ levels. Results through 2000 indicated that irrigation with $8 \mathrm{dS} \cdot \mathrm{m}^{-1}$ water containing $\mathrm{B}$ at 8 $\mathrm{mg} \cdot \mathrm{L}^{-1}$ produced no significant effect on marketable yield of trees (Ferguson et al., 2001).

Although we have found that pistachios perform well when irrigated with saline water by microsprinklers under field conditions in the SJV, soil variability and changing root-water extraction patterns make it difficult to compare rootstocks (Ferguson et al., 2001). Therefore, the objective of this research was to evaluate the performance (growth, ion relations, and potential ion toxicity) of $P$. vera budded on three popular California rootstocks irrigated with waters containing mixed $\mathrm{Cl}^{-}$and $\mathrm{SO}_{4}{ }^{2-}$ salinity and high $\mathrm{B}$ concentrations.

\section{Materials and Methods}

The experiment was conducted at the U.S. Department of Agriculture, Agricultural Research Service, George E. Brown, Jr., Salinity Laboratory, Riverside, Calif., in outdoor sand tanks. Scions of $P$. vera 'Kerman' were budded on each of three different rootstocks: $P$. atlantica, $P$. integerrima, and 'UCB-1', a cross of the two. Budded trees were obtained from a commercial nursery. Three trees, one of each scion-rootstock combination, were transplanted into each of 24 sand tanks on 16 Mar. 1999. The tanks, each $82 \mathrm{~cm}$ long $\times 202 \mathrm{~cm}$ wide $\times 84 \mathrm{~cm}$ deep, were filled with coarse sand having an average bulk density of $1.4 \mathrm{Mg} \cdot \mathrm{m}^{-3}$ and a volumetric water content at saturation of $0.34 \mathrm{~m}^{3} \cdot \mathrm{m}^{-3}$, and $0.1 \mathrm{~m}^{3} \cdot \mathrm{m}^{-3}$ after drainage nearly ceased. The 2 -year-old trees were uniformly trimmed to a single main trunk approximately $1 \mathrm{~m}$ tall before transplanting. The trees were irrigated three times daily with a nutrient solution containing (in $\mathrm{mol} \cdot \mathrm{m}^{-3}$ ) $4.0 \mathrm{Ca}^{2+}, 1.5$ $\mathrm{Mg}^{2+}, 15.5 \mathrm{Na}^{+}, 6 \mathrm{~K}^{+}, 7.8 \mathrm{SO}_{4}{ }^{2-}, 9.0 \mathrm{Cl}^{-}, 5.0 \mathrm{NO}_{3}^{-}, 0.2 \mathrm{H}_{2} \mathrm{PO}_{4}^{-}$,
$0.050 \mathrm{Fe}$ as sodium ferric diethylenetriamine pentaacetate (NaFeDTPA), $0.005 \mathrm{MnSO}_{4}, 0.0004 \mathrm{ZnSO}_{4}, 0.0002 \mathrm{CuSO}_{4}$, $0.0001 \mathrm{H}_{2} \mathrm{MoO}_{4}$, and $0.161 \mathrm{H}_{3} \mathrm{BO}_{3}$ prepared with city of Riverside, Calif., municipal water. The base nutrient solution, with an electrical conductivity $\left(\mathrm{EC}_{\mathrm{iw}}\right)$ of $3.5 \mathrm{dS} \cdot \mathrm{m}^{-1}$, served as the control treatment.

The completely randomized split plot experimental design consisted of four irrigation water qualities (final $\mathrm{EC}_{\mathrm{iw}}=3.5,8.7,12$, and $16 \mathrm{dS} \cdot \mathrm{m}^{-1}$ ) each with $\mathrm{B}$ at $10 \mathrm{mg} \cdot \mathrm{L}^{-1}$, and six replications. The irrigation waters were designed to simulate the saline-sodic drainage waters typical of those in the SJV of California. Composition of the salinizing salts is presented in Table 1. Treatments were imposed beginning on 21 Apr. 1999. Salts were added gradually over a 12$\mathrm{d}$ period to avoid osmotic shock to the trees. The $\mathrm{pH}$ ranged between 7.8 and 8.4. The irrigation waters were analyzed four times during the experiment by inductively coupled plasma optical emission spectrometry (ICPOES) to confirm that target concentrations of $\mathrm{Ca}^{2+}, \mathrm{Mg}^{2+}, \mathrm{Na}^{+}, \mathrm{K}^{+}, \mathrm{S}, \mathrm{P}$, and $\mathrm{B}$ were maintained. Chloride was determined by coulometric-amperometric titration.

Treatment irrigation waters were pumped from 1750-L reservoirs in an underground basement to the tanks and returned by gravity through a subsurface drainage system to maintain a uniform and constant profile of salinity and B (i.e., leaching fraction $>0.9$ ). Perforated polyvinyl chloride pipe on the sand surface delivered the applied water allowing the water to temporally pond $(<10 \mathrm{~min})$ on the sand surface. At each irrigation, the volume of applied water was at least nine times the maximal daily evapotranspiration (ET). Therefore, the salinity and ion composition of the sand water was very close to that of the irrigation water. Water in each storage reservoir lost to ET was replenished automatically each night.

Trunk diameters $10 \mathrm{~cm}$ above the bud union were measured to the nearest $0.01 \mathrm{~mm} 11$ times during the experiment with calipers oriented in the same direction for successive measurements. Leaf porometer measurements were conducted during June, July, and August on youngest fully expanded leaves on upper branches of the trees. All measurements were taken between midmorning and mid-afternoon on sunny days with a steady-state porometer (LI1600; LI-COR Inc., Lincoln, Neb.).

Leaf chlorophyll was determined over the course of the experiment. A SPAD-502 meter (Soil-Plant-Analysis-Development, Minolta Corp., Ramsey, N.J.)was used to take readings on similar leaves on five different days in July near the leaflet midrib, between the leaflet midrib and the margin, and near the margin. Leaf chlorophyll concentrations were assayed by the method of Arnon (1949). Total leaf chlorophyll concentration (micrograms per square centimeter) as a function of SPAD value was leaf chlorophyll $\left(\mu \mathrm{g} \cdot \mathrm{cm}^{-2}\right)=-87.3+73.2\left(\operatorname{Exp}\left(0.0145(\mathrm{SPAD}), r^{2}=0.85\right.\right.$.

Beginning 13 Oct. 1999, trees were harvested over a 2 -week period. For each tree the following measurements were recorded: number of branches from main trunk, trunk height, approximate canopy height, and distance of each branch base from the sand

Table 1. Composition of salinizing salts in solutions used to irrigate pistachio trees grown in outdoor sand cultures.

\begin{tabular}{lcrcrr}
\hline \hline \multirow{E}{*}{$\begin{array}{l}\text { i } \\
\left(\mathrm{dS} \cdot \mathrm{m}^{-1}\right)\end{array}$} & \multicolumn{5}{c}{ Salt $\left(\mathrm{mol} \cdot \mathrm{m}^{-3}\right)$} \\
\cline { 2 - 6 } & $\mathrm{Ca}^{2+}$ & $\mathrm{Mg}^{2+}$ & $\mathrm{Na}^{+}$ & $\mathrm{SO}_{4}^{2-}$ & \multicolumn{1}{c}{$\mathrm{Cl}^{-}$} \\
\hline 3.5 & 4.0 & 1.5 & 15.5 & 7.8 & 9.0 \\
8.7 & 8.2 & 6.5 & 58.2 & 29.5 & 28.4 \\
12.0 & 12.5 & 10.0 & 88.5 & 44.9 & 42.9 \\
16.0 & 13.5 & 15.5 & 137 & 64.0 & 66.4 \\
\hline
\end{tabular}


Table 2. Final growth parameters for 'Kerman' pistachio as influenced by salinity treatment and rootstock.

\begin{tabular}{|c|c|c|c|c|c|c|c|c|c|}
\hline \multirow{2}{*}{$\begin{array}{l}\mathrm{EC}_{\mathrm{iw}} \\
\left(\mathrm{dS} \cdot \mathrm{m}^{-1}\right)\end{array}$} & \multicolumn{3}{|c|}{$\begin{array}{l}\text { Shoot biomass } \\
\text { (g dry wt) }\end{array}$} & \multicolumn{3}{|c|}{$\begin{array}{c}\text { Canopy ht } \\
(\mathrm{cm})\end{array}$} & \multicolumn{3}{|c|}{$\begin{array}{l}\text { Trunk diam increase } \\
(\mathrm{mm})\end{array}$} \\
\hline & $P$. atlantica & P. integerrima & UCB-1 & P. atlantica & P. integerrima & UCB-1 & P. atlantica & P. integerrima & UCB-1 \\
\hline 3.5 & $630 a^{z}$ & $705 \mathrm{a}$ & $634 a b$ & $164 \mathrm{a}$ & $167 \mathrm{a}$ & $151 \mathrm{ab}$ & $6.2 \mathrm{a}$ & $4.5 \mathrm{a}$ & $7.6 \mathrm{a}$ \\
\hline 8.7 & 709 a & $634 \mathrm{a}$ & $663 \mathrm{a}$ & $160 \mathrm{a}$ & $168 \mathrm{a}$ & $165 \mathrm{a}$ & $5.8 \mathrm{a}$ & $5.0 \mathrm{a}$ & $6.9 \mathrm{a}$ \\
\hline 12 & $700 \mathrm{a}$ & $447 \mathrm{~b}$ & $478 \mathrm{bc}$ & $173 \mathrm{a}$ & $120 \mathrm{~b}$ & $132 \mathrm{ab}$ & $6.8 \mathrm{a}$ & $4.0 \mathrm{a}$ & $5.6 \mathrm{ab}$ \\
\hline 16 & $372 \mathrm{~b}$ & $302 \mathrm{c}$ & $366 \mathrm{c}$ & $119 \mathrm{~b}$ & $107 \mathrm{~b}$ & $126 \mathrm{~b}$ & $3.3 \mathrm{~b}$ & $1.1 \mathrm{~b}$ & $4.4 \mathrm{~b}$ \\
\hline $\mathrm{LSD}_{0.05}$ & 212 & 144 & 185 & 31 & 15 & 34 & 2.4 & 2.0 & 2.0 \\
\hline
\end{tabular}

${ }^{\mathrm{z}}$ Mean separation within columns by LSD, $P=0.05(\mathrm{n}=6)$.

surface. For each branch of each tree, the diameter at the branch base was measured as was branch length, number of leaves, fresh and DWs of stems, DWs of leaves (total and necrotic portions), and total and necrotic leaf area. Injured tissue was painstakingly cut from all injured leaves. Leaf area was determined with a leaf area meter (LI-3100; LI-COR). Ratios of injured and noninjured leaf sections were determined on an area and DW basis. All branches, stems and leaves were washed in deionzed water, dried in a forced-air oven at $60^{\circ} \mathrm{C}$ for $72 \mathrm{~h}$, weighed and ground to pass a 60 -mesh $(0.423-\mathrm{mm})$ screen.

Roots were removed from the harvested trees. Efforts were made to extract the bulk of the roots from each tree in this coarse sand, although no attempt was make to recover all the fine roots. Care was taken to separate roots that may have been tangled between rootstocks.

Cores of each tree trunk were taken $3 \mathrm{~cm}$ above and below the bud union after the trees were cut to provide wood samples from the scion and rootstock, respectively. Samples were dried for 72 $\mathrm{h}$ at $60^{\circ} \mathrm{C}$ and ground to pass a 60 -mesh $(0.423 \mathrm{~mm})$ screen.

Total S, total $\mathrm{P}, \mathrm{Ca}, \mathrm{Mg}, \mathrm{Na}$, and $\mathrm{K}$ were determined on nitricperchloric acid digests of the leaf and woody tissues by ICPOES. Chloride was determined on nitric-acetic acid extracts of the tissue by coulometric-amperometric titration. For B analysis, ground plant samples $(500 \mathrm{mg})$ were ashed, then dissolved in 2.5 $\mathrm{mL}$ nitric acid (7\%). The solution volume was adjusted to $25 \mathrm{~mL}$ with deionized water and analyzed by ICPOES.

During the course of the experiment, day/night air temperatures ranged from 2.8 to 39.4 (mean 22.8 $\left.{ }^{\circ} \mathrm{C}\right) / 2.0$ to 32.5 (mean $15.5^{\circ} \mathrm{C}$ ). Daily relative humidity $(\mathrm{RH})$ over the same period ranged from $2.2 \%$ to $94.6 \%$; mean day/night RH was $15.5 \% / 68.6 \%$.

Analysis of variance (ANOVA) and LSD tests were computed for the main salinity effects and subplot rootstock effects on the growth variables (SAS Institute, Inc., 1985). Evaluation of pistachio salt tolerance was conducted with the use of the exponential salinity yield response function of van Genuchten and Hoffman (1984): $Y=Y_{m} \exp$ $\left(\alpha c-\beta c^{2}\right)$, where $\mathrm{Y}$ is the relative yield, $\mathrm{Y}_{\mathrm{m}}$ is the yield under nonsaline conditions, and $\mathrm{c}$ is the threshold concentration. Log transformed, the equation is converted to a quadratic form that gives the concentration in the root zone where the yield is 50\% (i.e., $\mathrm{Y} /$ $\mathrm{Ym}=0.5)$. The log transformation also is preferred if the variability of the growth data decreases as the salinity increases (Wilson, et al., 2000), as was observed in the present experiment. Statistical analyses of the ion data were performed by ANOVA with mean comparisons at $P<$ 0.05 based on Tukey's studentized range test (SAS release version 6.12, SAS Institute, Inc., 1997).

\section{Results}

Growth PARAMETERs. Salinity decreased total shoot biomass, tree canopy height, trunk diameter increase, leaf area, and number of leaves of 'Kerman' pistachio, but these effects were not significant until levels reached or exceeded $12 \mathrm{dS} \cdot \mathrm{m}^{-1}$ (Table 2). Salt tolerance response functions, based on these growth parameters for each rootstock-scion combination, showed that the ECs resulting in a $50 \%$ decrease in scion growth $\left(\mathrm{C}_{50}\right)$ were $12.9(P$. integerrima) and $15.4\left(P\right.$. atlantica and ' $\mathrm{UCB}-1$ ') $\mathrm{dS} \cdot \mathrm{m}^{-1}$. As an example, the effect of rootstock on $P$. vera trunk diameter increase relative to the maximum absolute diameter increase for each rootstock-scion combination is shown in Fig. 1. Root biomass of $P$. atlantica, $P$. integerrima, and 'UCB- 1 ' decreased $45 \%, 48 \%$ and $40 \%$, respectively, as salinity increased from 3.5 to $16 \mathrm{dS} \cdot \mathrm{m}^{-1}$ (data not presented).

Fig. 1. Trunk diameter increase of 'Kerman' pistachio as a function of increasing electrical conductivity of the soil solution for three rootstocks- $P$. vera 'Kerman' scion combinations. Each symbol is the mean of six observations and vertical lines $=$ SE.

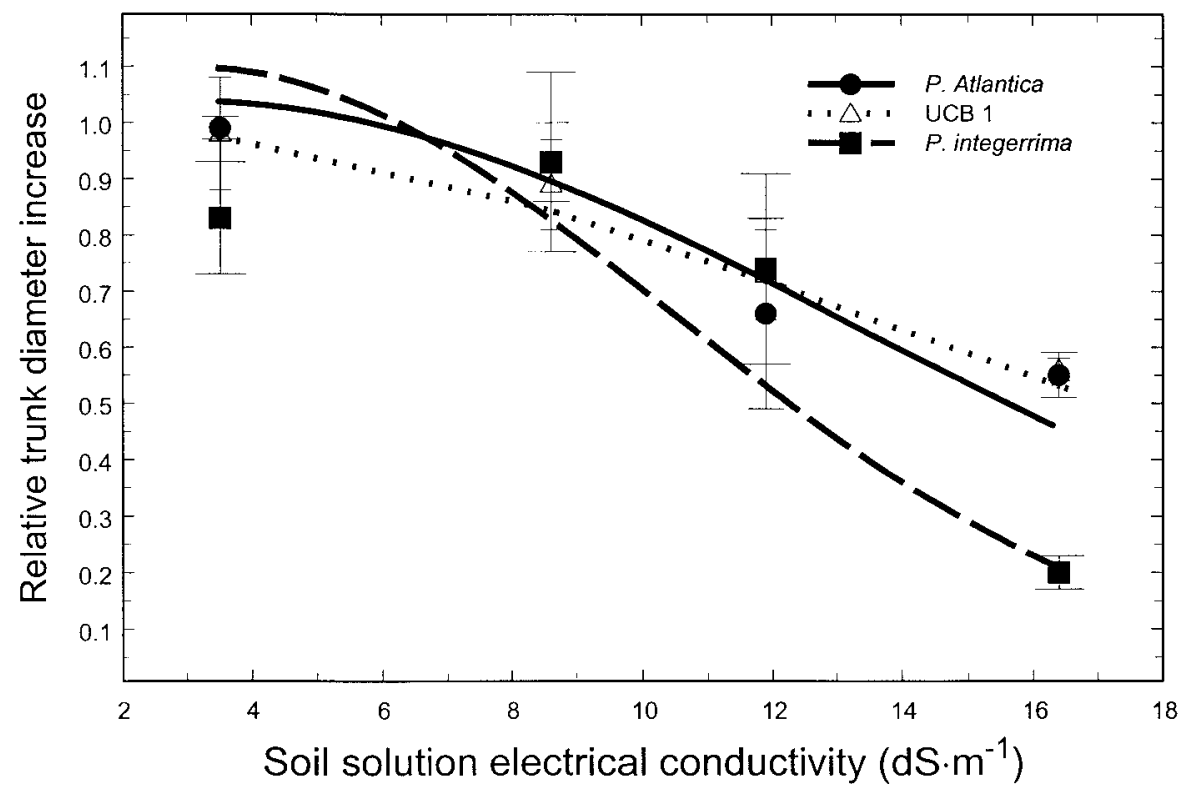


Table 3. Total leaf weight, leaf area, and leaf injury of 'Kerman' pistacio as influenced by salinity treatment and rootstock.

\begin{tabular}{|c|c|c|c|c|c|c|c|c|c|}
\hline \multirow{3}{*}{$\begin{array}{l}\mathrm{EC}_{\mathrm{iw}} \\
\left(\mathrm{dS} \cdot \mathrm{m}^{-1}\right)\end{array}$} & \multicolumn{3}{|c|}{$\begin{array}{l}\text { Total leaf wt } \\
(\mathrm{g})\end{array}$} & \multicolumn{3}{|c|}{$\begin{array}{c}\text { Total leaf area } \\
\left(\mathrm{cm}^{2} / \text { tree }\right)\end{array}$} & \multicolumn{3}{|c|}{$\begin{array}{c}\text { Injured area } \\
(\%)\end{array}$} \\
\hline & \multicolumn{9}{|c|}{ Rootstock } \\
\hline & P. atlantica & P. integerrima & UCB-1 & P. atlantica & P. integerrima & UCB-1 & P. atlantica & $P$. integerrima & UCB-1 \\
\hline 3.5 & $126 \mathrm{a}^{\mathrm{z}}$ & $161 \mathrm{a}$ & $149 \mathrm{a}$ & $5270 \mathrm{a}$ & $7061 \mathrm{ab}$ & $6620 a$ & $0.2 \mathrm{a}$ & $0.3 \mathrm{ab}$ & $0.2 \mathrm{a}$ \\
\hline 8.7 & $126 \mathrm{a}$ & $116 a b$ & $153 \mathrm{a}$ & $5761 \mathrm{a}$ & $7991 \mathrm{a}$ & $6991 \mathrm{a}$ & $0.1 \mathrm{ab}$ & $0.2 \mathrm{ab}$ & $0.1 \mathrm{~b}$ \\
\hline 12 & $113 \mathrm{a}$ & $79 \mathrm{bc}$ & $108 \mathrm{a}$ & 5489 a & $4252 \mathrm{bc}$ & $4536 \mathrm{ab}$ & $0.1 \mathrm{~b}$ & $0.1 \mathrm{~b}$ & $0.1 \mathrm{~b}$ \\
\hline 16 & $48 \mathrm{~b}$ & $36 \mathrm{c}$ & $57 \mathrm{~b}$ & $2107 \mathrm{~b}$ & $1194 \mathrm{c}$ & $2107 \mathrm{~b}$ & $0.1 \mathrm{~b}$ & $0.4 \mathrm{a}$ & $0.1 \mathrm{~b}$ \\
\hline $\mathrm{LSD}_{0.05}$ & 54 & 48 & 51 & 2603 & 3315 & 2537 & 0.1 & 0.2 & 0.08 \\
\hline
\end{tabular}

${ }^{\mathrm{z}}$ Mean separation within column by LSD, $P=0.05(\mathrm{n}=6)$.

Stomatal conductance of leaves of $P$. vera on $P$. atlantica was unaffected by salinity. However, as salinity increased from 3.5 to $16 \mathrm{dS} \cdot \mathrm{m}^{-1}$, stomatal conductance of trees on the other two rootstocks decreased $\approx 15 \%$ (data not presented). Average cumulative evapotranspiration for the aggregate three trees in each tank from low to high salinity were $2280 \pm 98,2424 \pm 101,1960 \pm 126$, and $1550 \pm 49 \mathrm{~L}$, respectively when averaged over the six replications.

Foliar INJURY. Slight marginal leaf chlorosis was first observed 10 Jun 1990 on a single tree of $P$. vera budded on 'UCB1 ' and irrigated with low salinity water $\left(3.5 \mathrm{dS} \cdot \mathrm{m}^{-1}\right)$ containing B at $10 \mathrm{mg} \cdot \mathrm{L}^{-1}$. Within $30 \mathrm{~d}$, slight to moderate leaf injury was evident on all trees, regardless of treatment, and the extent of injury increased over time. The injury was generally confined to leaves on the proximal branch section, whereas leaves on the distal sections often remained healthy or showed only slight marginal chlorosis. Damage was more severe on leaves of $P$. vera budded on $P$. atlantica and 'UCB-1' when the trees were irrigated with waters at low rather than higher salinities. For example, 19\% of the total area of the canopy of $P$. vera on 'UCB-1' was injured in the $3.5 \mathrm{dS} \cdot \mathrm{m}^{-1}$ treatment compared to $11 \%$ at the $16 \mathrm{dS} \cdot \mathrm{m}^{-1}$ treatment (Table 3). Leaves of trees on P. integerrima were more heavily damaged in the $16 \mathrm{dS} \cdot \mathrm{m}^{-1}$ treatment (i.e., $37 \%$ of total area) than on $P$. atlantica (9\%) or 'UCB-1' (11\%). No visible disorders of stem tissue in any of the trees were observed during the course of the experiment.

Chlorophyll estimates based on SPAD meter readings for trees on $P$. atlantica and 'UCB-1' decreased $\approx 10 \%$ from midrib to leaf margin when averaged over several survey dates and salinity levels, whereas chlorophyll in 'Kerman' leaves on $P$. integerrima decreased nearly $20 \%$ from midrib to margin. Leaves from $P$. integerrima at all salinity treatments and positions had lower chlorophyll concentrations than leaves from the other two rootstocks (data not presented). Considerable variation in this relationship was observed for SPAD readings $>50$, although the fitted curve (data not presented) was very similar to that reported by Monje and Bugbee (1992) for wheat (Triticum aestivum L.), rice (Oryza sativa L.), and soybean (Glycine max L.).

ION ACCUMULATION AND DISTRIBUTION. Boron analysis confirmed that leaf injury symptoms were due primarily to B toxicity. Identical symptoms (i.e., dark reddish necrosis on the margins of older leaves) have been observed in established pistachio orchards in the SJV, particularly towards the end of the summer (Ashworth et al., 1985; Ferguson and Grattan, personal observations). Boron concentrations were three to four times higher in the injured than in the uninjured tissue (Fig. 2). Further increases in salinity did not significantly affect these values. Leaves of $P$. vera on $P$. atlantica generally contained less $B$ and exhibited less injury than those on the other two rootstocks (Table 3 ). Boron concentration in woody tissue was $\approx 18.5 \mathrm{mg} \cdot \mathrm{kg}^{-1}$ regardless of salinity and was not partitioned differentially between rootstock and scion tissues (data not presented).

Sodium concentration in leaves increased significantly with salinity and was uniformly partitioned between the healthy and necrotic tissues. In the $16 \mathrm{dS} \cdot \mathrm{m}^{-1}$ treatment, $\mathrm{Na}^{+}$concentrations in $P$. vera leaves on $P$. atlantica, 'UCB-1', and $P$. integerrima were 145,87 , and $366 \mathrm{mmol} \cdot \mathrm{kg}^{-1} \mathrm{DW}$, respectively. All rootstocks retained significantly more $\mathrm{Na}^{+}$in woody tissue than was accumulated in 'Kerman' stems (Fig. 3). For 'UCB-1', this response became stronger as salinity increased, e.g., rootstock $\mathrm{Na}^{+} /$scion $\mathrm{Na}^{+}$increased from 3 to 8 as salinity increased from 3.5 to 16 $\mathrm{dS} \cdot \mathrm{m}^{-1}$, whereas this ratio for the other rootstocks remained at 3

Fig. 2. Distribution of B in healthy (hatched) and injured ( $\square$ plus hatched) leaves of 'Kerman' pistachio as influenced by three different rootstocks and increasing salinity. Values are means of six observations and vertical lines $=\mathrm{SE}$.

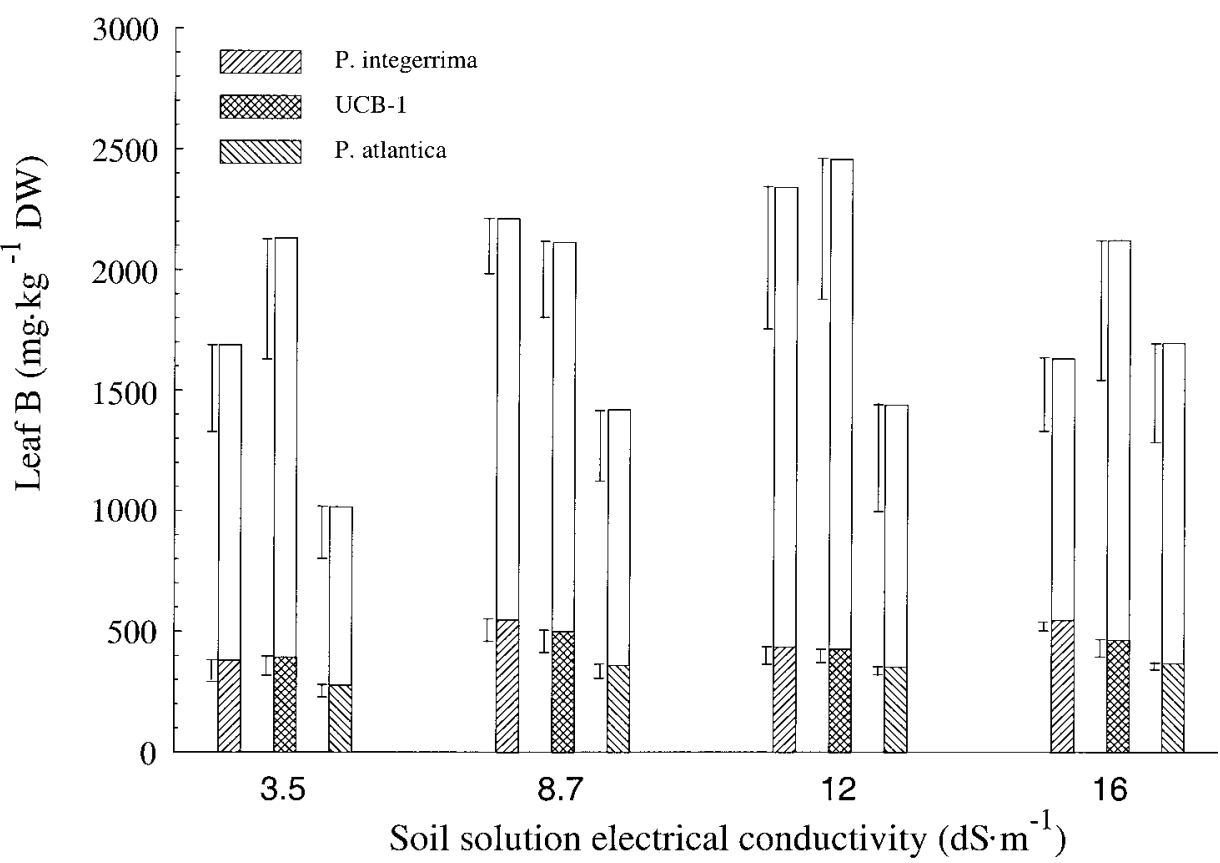




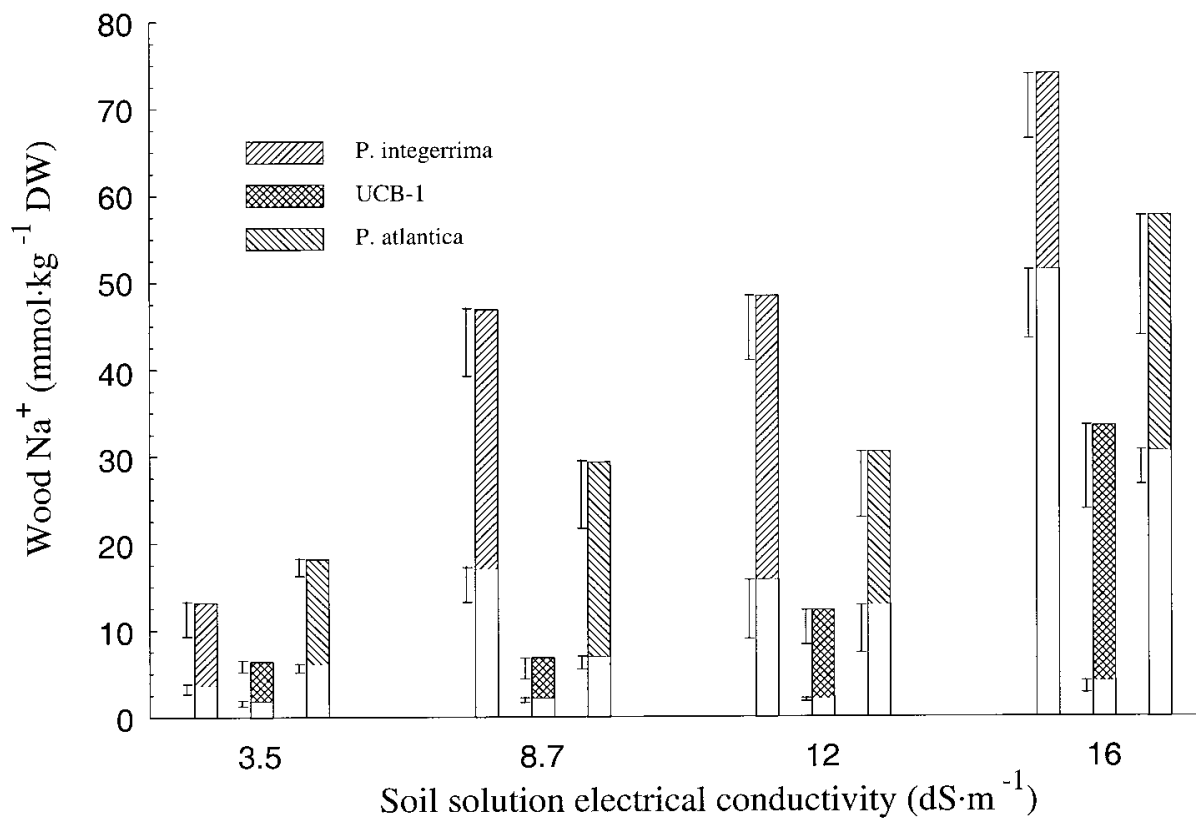

Fig. 3. Partitioning of $\mathrm{Na}^{+}$between 'Kerman' pistachio scion ( $\square$ ) and rootstock wood ( $\square$ plus hatched) as influenced by increasing salinity. Values are means of six observation and vertical lines $=\mathrm{SE}$.

until $\mathrm{EC}_{\mathrm{iw}}$ exceeded $12 \mathrm{dS} \cdot \mathrm{m}^{-1}$, then decreased to $\approx 1.5$.

Chloride was also uniformly distributed between healthy and injured leaf tissues. The $\mathrm{Cl}^{-}$excluding capability of pistachio appears to be less effective than the mechanism(s) that restrict $\mathrm{Na}^{+}$ to the leaves. For example, the $\mathrm{Na}^{+}$concentration in the external solution was double that of $\mathrm{Cl}^{-}$, yet leaf $\mathrm{Na}^{+}$concentrations were substantially lower than $\mathrm{Cl}^{-}$. 'Kerman' leaves on $P$ integerrima contained higher $\mathrm{Cl}^{-}$concentrations than on the other two rootstocks. Leaf $\mathrm{Cl}^{-}$in $P$. vera budded on $P$. integerrima increased $>4$ fold (122 to $521 \mathrm{mmol} \cdot \mathrm{kg}^{-1} \mathrm{DW}$ ), whereas leaf $\mathrm{Cl}^{-}$of trees on 'UCB-1' doubled as salinity increased from low to high levels (data not presented). Patterns of leaf $\mathrm{Cl}^{-}$concentration and partitioning between scion and rootstock wood generally followed those of $\mathrm{Na}^{+}$in that both monovalent ions were accumulated preferentially in the rootstock (Fig. 4).

Calcium concentration in healthy leaves of $P$. vera on all rootstocks decreased significantly with increasing salinity, despite a 3-fold increase in $\mathrm{Ca}^{2+}$ in the irrigation waters. Under nonsaline conditions, leaves of 'Kerman' on $P$.integerrima contained higher $\mathrm{Ca}^{2+}$ concentration than those on the other two rootstocks, a finding that has been reported previously for the same scion-rootstock combinations in several commercial pistachio orchards (Brown et al., 1994). Injured leaf sections showed three different responses to salinity that depended on rootstock, i.e., leaf $\mathrm{Ca}^{2+}$ decreased significantly from 344 to $267 \mathrm{mmol} \cdot \mathrm{kg}^{-1} \mathrm{DW}$ on trees on $P$. integerrima, increased significantly from 216 to $349 \mathrm{mmol} \cdot \mathrm{kg}^{-1} \mathrm{DW}$ on $P$.atlantica, and was unaffected $\left(\right.$ mean $\left.=355 \mathrm{mmol} \cdot \mathrm{kg}^{-1} \mathrm{DW}\right)$ by salinity on 'UCB-1'. Calcium in wood samples was not distributed differentially between scion and rootstock (data not presented).

Increases in salinity had no effect on $\mathrm{Mg}^{2+}$ in healthy 'Kerman' leaves on 'UCB-1' (mean $\left.=144 \mathrm{mmol} \cdot \mathrm{kg}^{-1} \mathrm{DW}\right)$ or on $P$. atlantica ( mean $=148 \mathrm{mmol} \cdot \mathrm{kg}^{-1} \mathrm{DW}$ ) despite a 10 -fold increase in external $\mathrm{Mg}^{2+}$. Healthy leaves on $P$. integerrima, however, decreased significantly (134 to $76 \mathrm{mmol} \cdot \mathrm{kg}^{-1} \mathrm{DW}$ ) as salinity increased. Salinity significantly reduced $\mathrm{Mg}^{2+}$ in necrotic leaves on 'UCB-1' (150 to 234 mmol $\left.\cdot \mathrm{kg}^{-1} \mathrm{DW}\right)$ and $P$. atlantica (105 to 171 $\left.\mathrm{mmol} \cdot \mathrm{kg}^{-1} \mathrm{DW}\right)$, but not on $P$. integerrima (mean $\left.=137 \mathrm{mmol} \cdot \mathrm{kg}^{-1} \mathrm{DW}\right)$. Neither salinity nor rootstock influenced stem $\mathrm{Mg}^{2+}$ and the concentration was $\approx 25 \mathrm{mmol} \cdot \mathrm{kg}^{-1} \mathrm{DW}$ in the wood of all scion and rootstock combinations (data not presented).

\section{Discussion}

The effect of combined salinity and B stress on either biomass production or trunk diameter increase in pistachio appears to be no different, or at best only slightly less, than under salinity stress alone. The EC of the sand solution resulting in $50 \%$ biomass reductions $\left(\mathrm{C}_{50}\right)$ relative to nonsaline controls was similar to that reported in studies where B was not elevated (Sepashkah and Maftoun, 1988). If one assumes that $\mathrm{EC}$ of soil water is twice that of $\mathrm{EC}_{\mathrm{e}}$ (Ayers and Westcot, 1985), then the $\mathrm{C}_{50}$ values reported by Sepashkah and Maftoun(1988) were between 15.8 and $20 \mathrm{dS} \cdot \mathrm{m}^{-1}$. Earlier Sepashkah et al. (1985) reported $\mathrm{C}_{50}$ values that were close to those reported here for trees on $P$. atlantica and ' $\mathrm{UCB}-1$ ' $\left(15.4 \mathrm{dS} \cdot \mathrm{m}^{-1}\right)$, butgreater than that observed for trees on $P$. integerrima $\left(12.9 \mathrm{dS} \cdot \mathrm{m}^{-1}\right)$. Our results for growth of 'Kerman' on 'UCB-1' are also similar to those reported by

Fig. 4. Partitioning of $\mathrm{Cl}^{-}$between 'Kerman' pistachio scion ( $\square$ ) and rootstock wood ( $\square$ plus hatched) as influenced by increasing salinity. Values are means of six observations and vertical lines $=$ SE.

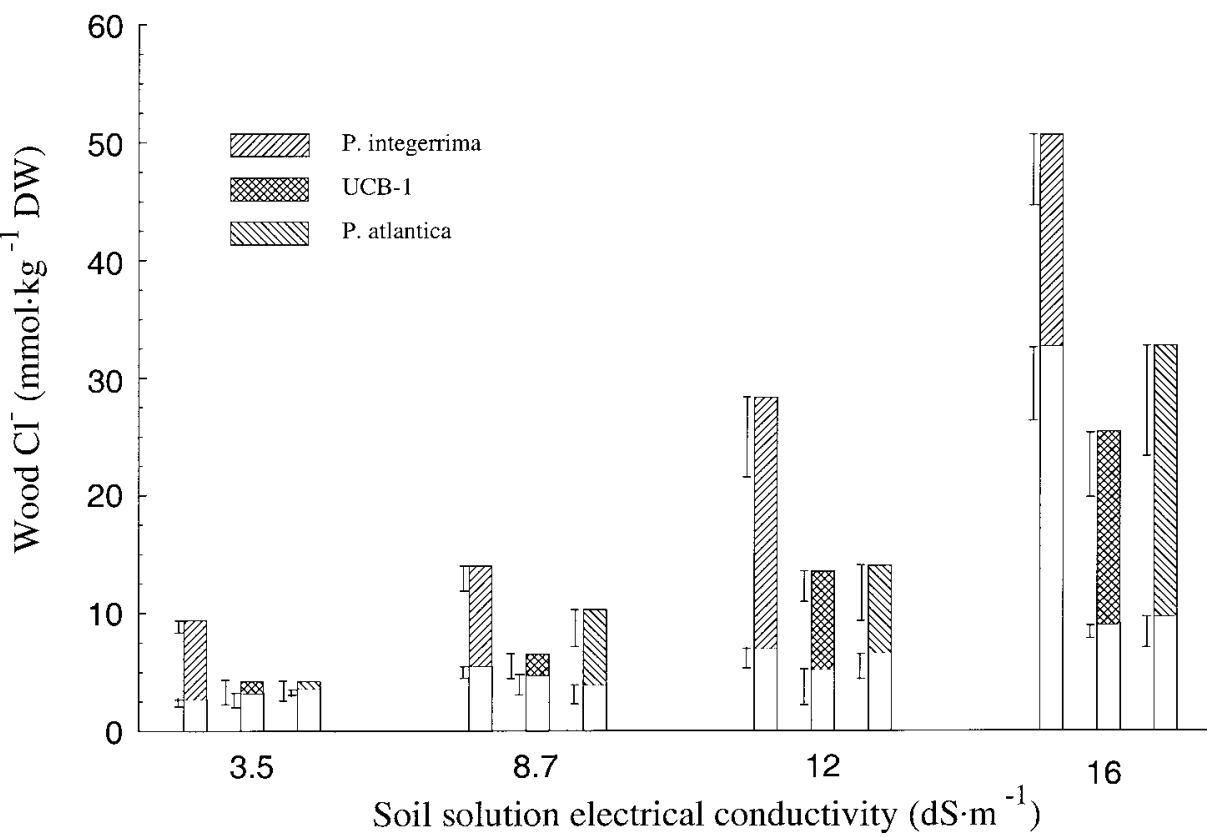


Picchioni et al. (1990) for seedling stem elongation of a similar seedling hybrid growing on its own roots.

Data herein provide strong evidence that B toxicity, rather than salinity, was the main cause of leaf injury. Concentrations of B in injured tissue were three to five times that in healthy tissue and in a range (1000 to $2500 \mathrm{mg} \cdot \mathrm{kg}^{-1} \mathrm{DW}$ ) that is considered lethal for pistachio (Ashworth et al., 1985). Patterns of injury in the leaves followed typical symptoms of an excessive B supply (Marschner, 1995). The steep gradient in B concentration (middle of leaf blade $<$ leaf margin) also reflected increase in leaf injury along with a decrease in chlorophyll concentration. The long-term effect of this substantial reduction of healthy leaf area at high external B concentrations is unknown. Such detailed studies on the B tolerance of pistachio are needed to evaluate longer term B effects on biomass and nut yield. We are hopeful that our companion field study (Ferguson et al., 2001) will help shed light on this issue.

El-Motaium et al. (1994) reported reductions in B uptake, accumulation, and B toxicity symptoms in stems of several Prunus L. sp. rootstocks irrigated with saline waters comprised of both $\mathrm{SO}_{4}{ }^{2-}$ and $\mathrm{Cl}^{-}$salts. These investigators also found a negative relationship between $\mathrm{B}$ and $\mathrm{SO}_{4}{ }^{2-}$ concentrations in stem tissue and suggested that $\mathrm{SO}_{4}{ }^{2-}$ could be responsible for the salinityinduced decreases in tissue B. Although we did not find that salinity reduced foliar B concentrations, we observed that leaves were less damaged on trees irrigated with $16 \mathrm{dS} \cdot \mathrm{m}^{-1}$ waters than those irrigated with less saline waters.

Although leaf B concentrations were clearly at toxic levels in the present study, it is interesting that the decreased injury observed with increasing salinity was not accompanied by a significant reduction in leaf $\mathrm{B}$ concentration. It is possible that some internal $\mathrm{B}$-ion interaction was taking place that reduced the otherwise toxic effect of B. Salinity-B interactions of this type have been described elsewhere (Grattan and Grieve, 1999).

Elevated $\mathrm{Cl}^{-}$and $\mathrm{Na}^{+}$concentrations (nearly $1.8 \%$, and $0.8 \%$, respectively) in $P$. vera leaves on $P$. integerrima at $16 \mathrm{dS} \cdot \mathrm{m}^{-1}$ may have also been responsible for the injury observed in this rootstock-scion combination. This increased injury may have been the result of its overall poor growth performance at this salinity level. Foliar $\mathrm{Cl}^{-}$was relatively low in $P$. vera on $P$. atlantica and 'UCB-1' $\left(\mathrm{Cl}^{-}<300 \mathrm{mmol} \cdot \mathrm{kg}^{-1} \mathrm{DW}\right)$ and only about half that reported to cause $\mathrm{Cl}^{-}$injury in pistachio (Ashworth et al., 1985).

Chlorophyll concentrations per leaf area determined in this study ( 53 to $85 \mu \mathrm{g} \cdot \mathrm{cm}^{-2}$ ) are similar to those reported by Behboudian et al. (1986) who found that $P$. vera seedlings grown in solutions ranging from 0 to $400 \mathrm{~mm} \mathrm{Cl}^{-}$contained from 56 to $85 \mu \mathrm{g} \cdot \mathrm{cm}^{-2}$ chlorophyll. A significant reduction in leaf chlorophyll, as measured on a transect from near the midrib to the chlorotic leaf margins, also provides evidence of a good relation with leaf chlorophyll.

Based on our sand tank study, it would appear that $P$. atlantica would be the rootstock of choice for saline-sodic conditions high in $\mathrm{B}$. This rootstock reduces the amount of B that reaches the scion leaves compared to the other two rootstocks. If trees were grown under saline conditions alone, both $P$. atlantica and ' $U C B-1$ ' may be better choices than $P$. integerrima. Caution is advised, however, as our study only considered combined salinity-B stresses. Under actual soil conditions, root pathogens or other stresses may also play a major role in rootstock selection.

The interaction of B and salinity on long-term growth and final nut yield for pistachio warrants further attention. Boron toxicity appears to be mitigated under conditions of increasing salinity in Eucalyptus camaldulensis Dehn. (Poss et al, 1999) and, in the current study of pistachio, this response is supported by more severe injury at low, as compared to high salinities. Although Brown et al. (1994) indicated that $P$. atlantica was superior to the other rootstocks in obtaining $B$ under deficiency conditions, our study demonstrated that at high $\mathrm{B}$ concentrations, $P$. atlantica was least susceptible to leaf injury from B toxicity, indicating that other factors are involved in regulating $\mathrm{B}$ concentrations in pistachio leaves.

\section{Literature Cited}

Arnon, D.E. 1949. Copper enzymes in isolated chloroplasts: Polyphenol oxidase in Beta vulgaris. Plant Physiol. 24:1-15.

Ashworth, Jr., L.J., S.A. Gaona, and E. Surber. 1985. Nutritional diseases of pistachio trees: Potassium and phosphorus deficiencies and chloride and boron toxicities. Phytopathology 75:1084-1091.

Ayers, R.S. and D.W. Westcot. 1985. Water quality for agriculture. Food Agr. Org. Irr. Drainage Paper 29. FAO United Nations, Rome.

Behboudian, M.H., R.R. Walker, and E. Törökfalvy. 1986. Effects of water stress and salinity on photosynthesis of pistachio. Scientia Hort. 29:251-261.

Brown, P.H., Q.Zhang, and L. Ferguson. 1994. Influence of rootstock on nutrient acquisition by pistachio. J. Plant Nutr. 17:1137-1148.

El-Motaium, R., H. Hu, and P.H. Brown. 1994. The relative tolerance of six Prunus rootstocks to boron and salinity. J. Amer. Soc. Hort. Sci. 119:1169-1175.

Ferguson, L., B.L. Sanden, S.R. Grattan, H. Reyes, C. Wilson, and E. Cross. 2001. Potential for using blended drainage water for irrigating West Side, San Joaquin Valley pistachios. Calif. Pistachio Comm., Fresno, Annu. Proposal and Rpt.

Grattan, S.R. and C.M. Grieve. 1999. Salinity-Mineral nutrient relations in horticultural crops. Scientia Hort. 78:127-157.

Maas, E.V. and S.R. Grattan. 1999. Crop yields as affected by salinity, p. 55-108. In: R.W. Skaggs and J. van Schilfgaarde (eds.). Agricultural drainage. Amer. Soc. Agron./Crop Sci. Soc. Amer./Soil Sci. Soc. Amer., Madison, Wis., Agron. Monogr. 38.

Marschner, H. 1995. Mineral nutrition of higher plants. Academic Press, New York.

Monje, O.A. and B. Bugbee. 1992. Inherent limitations of nondestructive chlorophyll meters-A comparison of two types of meters. HortScience 27:69-71.

Picchioni, G.A., S. Miyamoto, and J.B. Storey. 1990. Salt effects on growth and ion uptake of pistachio rootstock seedlings. J. Amer. Soc. Hort. Sci. 115:647-653.

Poss, J.A., S.R. Grattan, C.M. Grieve, and M.C. Shannon. 1999. Characterization of leaf boron injury in salt-stressed Eucalyptus by image analysis. Plant Soil 206:237-245.

SAS Institute, Inc. SAS user's guide: Statistics. 1985. SAS Inst., Inc., Cary, N.C.

SAS Institute, Inc. 1997. SAS/STAT software: Changes and enhancements through release 6.12. SAS Inst., Inc., Cary, N.C.

Sepaskhah, A.R. and M. Maftoun. 1988. Relative salt tolerance of pistachio cultivars. J. Hort. Sci. 63:157-162.

Sepaskhah, A.R. and M. Maftoun. 1994. Seedling growth and chemical composition of two pistachio cultivars as affected by boron and nitrogen applications. J. Plant Nutr. 17:155-171.

Sepaskhah, A.R., M. Maftoun, and N. Karimian. 1985. Growth and chemical composition of pistachio as affected by salinity and applied iron. J. Hort. Sci. 60:115-121.

van Genuchten, M.Th. and G.J. Hoffman. 1984. Analysis of crop salt tolerance data, p. 258-271. In: I. Shainberg and J. Shalhevet (eds.). Soil salinity under irrigation: Processes and management. Ecological studies 51. Springer-Verlag, New York.

Walker, R.R., E. Törökfalvy, and M.H. Behboudian. 1987. Uptake and distribution of chloride, sodium, and potassium ions and growth of salttreated pistachio plants. Austral. J. Agr. Res. 38:383-394.

Wilson, C., S.M. Lesch, and C.M. Grieve. 2000. Growth stage modulates salinity tolerance of New Zealand spinach (Tetragonia tetragonioides, Pall) and red orach (Atriplex hortensis, L.). Ann. Bot. 85:501-509. 